\title{
Genetic Diversity and Structure of Native Egyptian Cattle Populations and French-Egyptian Cross via DNA-Microsatellite
}

\author{
Faid-Allah $\mathrm{E}^{1}$, Ghoneim $\mathrm{E}^{1}$, Elbetagy $\mathrm{AR}^{2}$, El-Dabour $\mathrm{M}^{1}$ \\ ${ }^{1}$ Department of Animal Production, Faculty of Agriculture, Menufia University, Egypt \\ ${ }^{2}$ Department of Animal Biotechnology, Animal Prod. Res. Institute, Agric. Res. Center, Egypt \\ E-mail: ifaidallah@yahoo.com
}

(received 06-12-2017; revised 28-01-2018; accepted 02-02-2018)

\begin{abstract}
ABSTRAK
Faid-Allah E, Ghoneim E, Elbetagy AR, El-Dabour M. 2018. Perbedaan dan struktur genetic populasi sapi Mesir lokal dan persilangan sapi Perancis-Mesir melalui penandaan DNA Mikrosatelit. JITV 23(1): 1-10. DOI: http://dx.doi.org/10.14334/jitv.v23i1.1647

Penelitian ini bertujuan untuk mempelajari perbedaan dan struktur genetik populasi sapi Mesir lokal Baladi jenis Saidi yang berasal dari Mesir bagian selatan, Menufi dari Mid-Delta dan persilangan F1 keduanya dengan jenis Taretaise Perancis melalui penandaan DNA Microsatelit. Sebanyak 97 ekor sapi yang tidak berhubungan dianalisis secara genotip menggunakan 8 primer SSR (ETH10, ETH225, BM1818, BM1824, BM2113, SPS115, TGLA53 dan TGLA126). Seluruh SSR yang digunakan mernunjukkan sifat polimorfik. Jumlah tertinggi dan terendah alel adalah 16 pada loci TGLA53 dan 6 pada loci SPS115. Persilangan Baladi-Tarentaise memiliki jumlah alel terbanyak secara keseluruhan. Nilai informasi polimorfik (PIC) pada 7 loci lebih tinggi dibandingkan dengan loci 0,5 yang mengindikasikan variasi alel yang tinggi pada penanda yang digunakan. Nilai perkiraan PIC bertutur-turut adalah 0.898; 0,866 dan 0.873 untuk loci TGLA53 dari genotipikasi sapi Saidi, Menufi dan Bal-Tar. Nilai heterozigositas yang diamati lebih rendah dibandingkan dengan nilai perkiraannya pada populasi lokal diikuti dengan nilai $F_{\text {is }}$ positif dan deviasi yang signifikan dari HWE yang mengindikasikan kecenderungan perkawinan sedarah di dalam populasi lokal tersebut. Analisis struktur mengindikasikan bahwa tiga genetik tetua. Populasi sapi lokal tersebut membagi dua asal tetua utama dengan persentase yang hampir seimbang, sementara itu persilangan Bal-Tar memiliki asal tetua ketiga. Ketiga populasi menunjukkan persentase campuran yang rendah. Populasi sapi Mediterrania yang dipelajari berasal dari Mesir dan Perancis sepertinya telah dibedakan satu sama lain dengan sedikit pertukaran genetik antar yang populasi yang terisolasi secara geograpis sehingga sapi lokal memiliki kemiripan yang tinggi.
\end{abstract}

Kata Kunci: Sapi, Keanekaragaman Genetik, Mikrosatelit DNA

ABSTRACT

Faid-Allah E, Ghoneim E, Elbetagy AR, El-Dabour M. 2018. Genetic diversity and structure of native Egyptian cattle populations and French-Egyptian Cross via DNA-microsatellite. JTTV 23(1): 1-10. DOI: http://dx.doi.org/10.14334/jitv.v23i1.1647

sThis study investigates genetic diversity and structure of native Egyptian cattle populations, called Baladi, as Saidi from Southern Egypt, Menufi from Mid-Delta and their F1 crosses with the French Tarentaise breed using DNA Microsatellite markers. A total of unrelated 97 individuals were genotyped utilizing eight SSR primers (ETH10, ETH225, BM1818, BM1824, BM2113, SPS115, TGLA53 and TGLA126). All utilized SSR were found to be polymorphic. The highest and lowest numbers of alleles detected were 16 and 6 at TGLA53 and SPS115 loci, respectively. Baladi-Tarentaise crosses (Bal-Tar) had the highest number of alleles over all. The PIC values of 7 loci were higher than 0.5, indicating high allelic variation of utilized markers. Estimated PIC values were up to $0.898,0.866$ and 0.873 for TGLA53 genotyped in Saidi, Menufi and Bal-Tar, respectively. Hobs values were lower than the expected ones in the native populations accompanied with positive values for $F_{\text {is }}$ and significant deviation from HWE indicating inbreeding trend in native populations. Structure analysis indicated three ancestral genetic backgrounds. The native populations share two main backgrounds in almost equal percentages, while the Bal-Tar had the third one. The three populations showed low percentage of admixture. The studied Mediterranean cattle populations that belong to Egypt and France seem to have differentiated from each other with only little genetic exchange between the geographically isolated populations so local cattle is very similar.

Key Words: Cattle, Genetic Diversity, DNA Microsatellite

\section{INTRODUCTION}

Cattle are an important source of meat and milk in Egypt. They are distributed all over the country, with higher density in the Nile valley and delta and usually found in small holdings along with buffaloes. The
Egyptian native cattle, called Baladi, had four breeds, being Domiati, Mariuti, Menufi, and Saidi (MoDAD 2004), that are defined mainly according to geographical distribution and minor phenotypic variations. Cattle breeds in Egypt lack molecular characterization required for establishing adequate 
utilization of their genetic variation for the improvement of cattle production under the challenging local conditions.

Cattle genetic improvement schemes in Egypt have involved crossbreeding with exotic high producing cattle breeds such as Holstein, Brown Swiss, Friesian and Simmental (MoDAD 2004), in addition to Abondance and Tarentaise as dual purpose French breeds. Tarentaise cattle, descends from the French Savoie cattle, was chosen for its adaptability to tough conditions. It makes good use of rough forage, withstands temperature variation, adapt well to arid zone, perceived as hardy, proving robust and resistant, and recognized as easy-calving breed. This remarkable all-purpose blend of hardiness, milk and beef production has carried the breed's reputation abroad in North Africa, especially Tunisia and Egypt. Utilization of the Tarentaise breed in Egypt started in 1996 within the program called "Franco-Egyptian Development Plan for AI and Selection" during five years from 1996 to 2001, which was successful and therefore extendable for an extra five years; up till 2006. The program aimed to the production of 20,000 crossbred Baladi-Tarentaise (Bal-Tar) females for the improvement of cattle production in Egypt. The appearance of the Baladi-
Tarentaise crosses resembles the Egyptian cows (Figure 1 ), reflecting the risk of uncontrolled gene flow to the native from the crossbred, and therefore the decay of pure native cattle genetic resources. Under such circumstances, studying the genetic variation and allele distribution within and among native and Bal-Tar cattle populations is crucial and time-effective. The findings of such study will contribute to the conservation and utilization of the native cattle genetic resources.

Microsatellite analyses have provided useful genetic information for African, European, mid-South American and Asian cattle breeds as reported by Dadi et al. (2008), Padilla et al. (2009), Acosta et al. (2013) and Pham et al. (2013), respectively. Microsatellites have been effectively exploited to evaluate genetic diversity among cattle populations (Sun et al. 2007).

The aims of this study were using DNA Microsatellite markers for studying the genetic diversity and structure of two major native cattle populations as Menufi and Saidi, and its crosses with Tarentaise breed, to identify genetic differentiation among the studied three Mediterranean cattle populations for the purpose of identification, utilization and conservation of indigenous native cattle genetic resources.

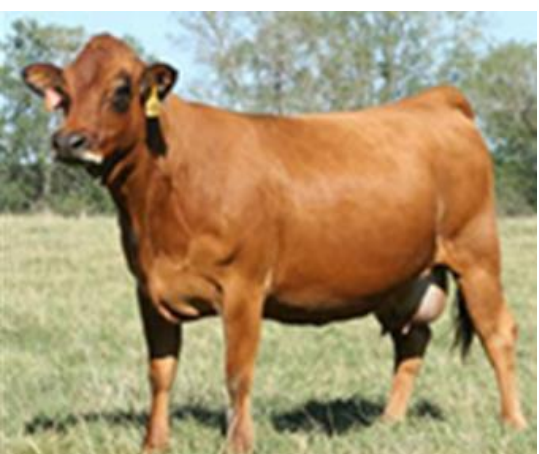

Tarentaise cow (http://www.thecattlesite.com/breeds/beef/47/tarentaise/)

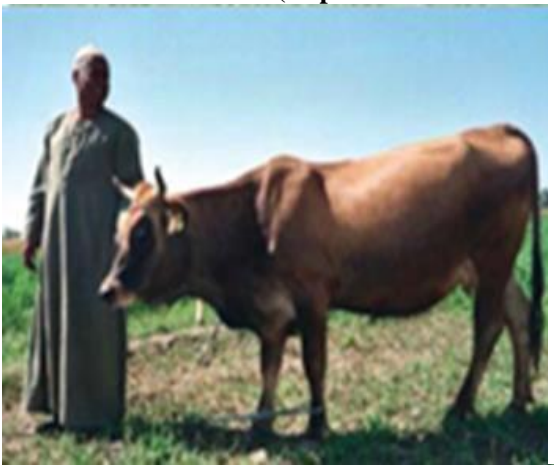

Baladi-Tarentaise (F1) cow



Tarentaise bull

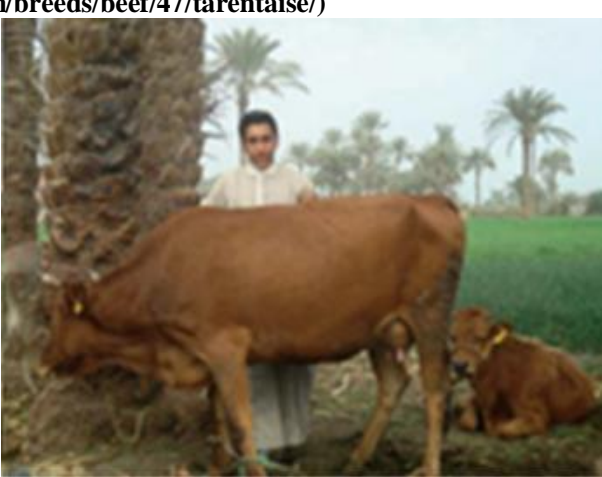

Baladi-Tarentaise (F2) cow

Figure 1. Visual appearance of Tarentaise cattle and their crosses with Egyptian Baladi cattle. 


\section{MATERIALS AND METHODS}

\section{Animals and sample collection}

Blood samples representing unrelated animals were collected and utilized for obtaining genomic DNA from the two Egyptian native cattle populations and Bal-Tar crossbred (Figure 1). A total 97 random blood samples: 41 samples of Saidi cattle that were collected from Quena to Beni-sweif governorates at Upper Egypt, 21 samples of Menufi cattle that were collected from Zewair and Shanshour districts at Minufia governorate, and from El-Serw Research Station, Animal Production Research Institute. The 35 Bal-Tar crosses samples were collected from crosses with Saidi cattle from Quena to Beni-sweif governorates at Upper Egypt and crosses with Menufi cattle from El-Serw Research Station.

Egyptian cattle (Baladi) are medium-sized, longbodied, lean of musculature and lightly boned. Medium length head, Face profile is straight or very slightly convex. Orbital arches are slightly accentuated, giving a small degree of concavity to the forehead. Poll is flat and Horns are short and grow from Poll laterally, curving forward so that their inclination is approximately at right angles to the line of the profile. Ears are moderate size. Neck is medium length and tends, in the female, to be lean. Dewlap and umbilical fold are small. Crest is accentuated in bull but it is only in the Saidi sub-type that a small cervico-thoracic hump is apparent in female. Rump is of very moderate slope and the accentuated tail setting is often higher than the withers. Body is long with only moderate depth and the ribs tend to be flat. Top-line dips in its central part between withers and prominent hook bones and bottom line rises from front to rear. Tail is moderate length. Thighs are flat and the limbs are long, lean and lightly boned. Coat coloration varies from fawn to red (Joshi et al. 1957).

\section{Microsatellites genotyping}

DNA was extracted from blood samples using Qiagen DNeasy® Blood and Tissue Kits according to manufacturers' instructions. DNA concentration was evaluated spectrophotometrically with Eppendorf $\AA$ Biophotometer. Eight microsatellites including ETH10, ETH225, BM1818, BM1824, BM2113, SPS115, TGLA53 and TGLA126 as shown in Table (1) were genotyped in the 97 samples. Markers were selected for their reported polymorphism and allele size range from those recommended in Measurement of Domestic Animal Diversity (MoDAD 2004).

The eight microsatellites were amplified in two PCR multiplex reactions, each containing 100-150 ng templates DNA, 1X Platinum ${ }^{\circledR}$ Multiplex PCR Master Mix (Lifetechnologies ${ }^{\circledR}$ ) and $10 \mathrm{pM}$ of each primer (4 primer pairs in each multiplex) in 25 ul total reaction volume. The thermal profile followed by the ISAG/FAO Panel and was run on a C1000 Thermal

Table 1 Microsatellite markers genotyped and its observed allele size in studied animals

\begin{tabular}{|c|c|c|c|}
\hline $\begin{array}{l}\text { SSR } \\
\text { (Chromosomal } \\
\text { Location) }\end{array}$ & $\begin{array}{l}\text { Observed allele size } \\
\text { range, bp }\end{array}$ & Primer Sequence & Reference \\
\hline BM1818 (D23S21) & $258-280$ & $\begin{array}{l}\text { F: AGCTGGGAATATAACCAAAGG } \\
\text { R: AGTGCTTTCAAGGTCCATGC }\end{array}$ & \\
\hline BM1824 (D1S34) & $179-193$ & $\begin{array}{l}\text { F: GAGCAAGGTGTTTTTCCAATC } \\
\text { R: CATTCTCCAACTGCTTCCTTG }\end{array}$ & Bishop \& Kappes (1994) \\
\hline BM2113 (D2S26) & $120-144$ & $\begin{array}{l}\text { F: GCTGCCTTCTACCAAATACCC } \\
\text { R: CTTAGACAACAGGGGTTTGG }\end{array}$ & \\
\hline ETH10 (D5S3) & $205-223$ & $\begin{array}{l}\text { F: GTTCAGGACTGGCCCTGCTAACA } \\
\text { R: CCTCCAGCCCACTTTCTCTTCTC }\end{array}$ & Toldo \& Fries (1993) \\
\hline ETH225 (D9S1) & $139-157$ & $\begin{array}{l}\text { F: GATCACCTTGCCACTATTTCCT } \\
\text { R: ACATGACAGCCAGCTGCTACT }\end{array}$ & Steffen \& Eggen (1993) \\
\hline SPS115 (D15) & $244-256$ & $\begin{array}{l}\text { F: AAAGTGACACAACAGCTTCTCCAG } \\
\text { R: AACCGAGTGTCCTAGTTTGGCTGTG }\end{array}$ & Moore \& Byrne (1993) \\
\hline TGLA53 (D16S3) & $151-181$ & $\begin{array}{l}\text { F: GCTTTCAGAAATAGTTTGCATTCA } \\
\text { R: ATCTTCACATGATATTACAGCAGA }\end{array}$ & Georoes \& Massev (1992) \\
\hline TGLA126 (D20S1) & $117-129$ & $\begin{array}{l}\text { F: CTAATTTAGAATGAGAGAGGCTTCT } \\
\text { R: TTGGTCTCTATTCTCTGAATATTCC }\end{array}$ & Georges \& ivassey (1992) \\
\hline
\end{tabular}


Cycler (Biorad (B). Genotyping and determination of single strand allele size for PCR amplicons were performed using the ABI3500 Genetic Analyzer (Lifetechnologies ${ }^{\circledR}$ ) using the GeneScan ${ }^{\circledR} 600$ LIZ® internal lane size standard. Allele size calling were carried out with GeneMapper (Applied Biosystems ${ }^{\circledR}$ ).

\section{Computations and statistical analysis}

Frequencies and number of alleles for each locus, observed and expected heterozygosity, Wright's statistics $F_{\text {is }}$ and $F_{\text {st }}$ were estimated via FSTAT (Goudet 2001). GENEPOP (Raymond \& Rousset 1995) was used to estimate Hardy-Weinberg equilibrium over loci within each population. Private alleles for any population was considered as those alleles unique for a population and detected in at least $25 \%$ of the sample of the population. The polymorphic information content (PIC) values were calculated according to Botstein et al. (1980).

Nei's (Nei 1987) standard genetic distances among populations were computed by POPGENE (Yeh et al. 1999). A pairwise matrix of the genetic distances was then used to obtain a Neighbor-joining (NJ) tree (Saitou $\&$ Nei 1987), which was visualized using the software FigTree (Rambaut 2012).

Bootstraps of 1000 replicates were performed in order to test the robustness of tree topology using the DISPAN (Ota 1993). The population structure was evaluated based on a Bayesian clustering analysis by employing structure (Pritchard et al. 2000), using multilocus genotypes to infer for all the individuals and populations for the fractions in their genetic ancestry that belong to a given number (k) of clusters. A Monte Carlo Markov chain was run for $\mathrm{k}=2$ to 3 , with a burnin period of 20,000 and a run length of 20,000 iterations. A default setting assuming an admixture model with correlated allele frequencies was used in all runs. The Delta $\mathrm{K}$ approved that the optimum $\mathrm{K}$ is 3 .

\section{RESULTS AND DISCUSSION}

\section{Allelic distribution and private allele}

Table 2 shows that microsatellites used in the present study were polymorphic for the three populations studied which revealed the existence of considerable genetic variability among the animals sampled. The highest number of alleles was 16 at TGLA53 and the lowest was 6 at SPS115. Bal-Tar cross had the highest total and mean number of alleles over all loci as 68 and $8.5 \pm 3.8$ alleles, respectively; which should be due to recombination of first generation crossbred. Saidi and Menufi populations also showed less but considerable number of alleles as 64 and 62 alleles, respectively. Studied populations showed presented genetic polymorphism proved by the considerable detected high total and mean number of alleles. Most loci proved to be highly polymorphic in native and its crosses. These results were in agreement with a mean 8.4 alleles per locus obtained by MacHugh et al. (1997) in Taurine and Zebu cattle populations, while it was higher than the mean of 6.5 alleles per locus reported by Beja-Pereira et al. (2003) in Iberian and French cattle breeds.

Obtained results are higher than those reported by Molina-Flores et al. (2011) for Saidi cattle being 6.25 alleles using 28 microsatellites and less than what reported by Hassanane et al. (2006), being 9 alleles in five local Egyptian populations in Delta, North and Mid-Egypt. Also, Cymbron et al. (2005) worked on different cattle populations utilizing 19 microsatellite loci and found much lower means number of alleles were $5.57 \pm 0.2,3.81 \pm 0.15$ and $4.29 \pm 0.16$ alleles for 32 animals of Egyptian native population, 38 animals of Salers and 27 animals of Vosges as French breeds, respectively.

In this study one private allele (PA) was found in Menufi population with frequency $=0.25$ and size $=205$ bp for ETH10 marker and two private alleles were found in Bal-Tar cross with frequency $=0.37$, size $=191$ bp for BM1824 marker and frequency $=0.27$, size $=119$ bp for TGLA128 marker as presented in Table (2).

Luo et al. (2006) used ten SSR to detect the genotypes of ten Chinese cattle breeds and 3 introduced breeds, the results showed that there were 117 alleles from the 10 SSR loci in 13 populations, which alleles of HEL9 carry the most number (18), ILSTS01 was the least (7). Number of alleles in the remaining seats was between 8 and 14, Dominant alleles of 13 Chinese and foreign breeds were mainly composed of ILSTS011, INRA035 and ILSTS005.

Suh et al. (2014) reported that a total of 276 alleles were detected at 30 microsatellite loci across four Korean native cattle breeds (Hanwoo, Chikso, Heugu, and Jeju black). The total number of alleles per locus ranged from 4 (ILSTS005) to 17 (TGLA122), with a mean of $9.20 \pm 0.58$ alleles.

\section{Polymorphic information content (PIC)}

The PIC is a parameter indicative of the informative degree of a marker. The PIC values range from zero to one. Loci with many alleles and higher PIC values up till one are the most desirable markers and PIC of $>0.5$ indicates a highly informative locus for chromosomal mapping and genetic diversity (Botstein et al. 1980). Microsatellites display a high degree of polymorphism, with a mean PIC of 0.6 (Vaiman et al. 1994). Most of the loci were highly informative (PIC $>0.5)$, with the exception of ILSTS005 (0.375) and HEL13 (0.413). Similarly, ILSTS005 and HEL13 have been reported to 
be the relatively low informative markers (Padilla et al. 2009).

The PIC values for all the eight markers are shown in Table (2). Average of PIC values for the eight microsatellites was 0.696 , ranged from 0.238 for SPS115 to 0.898 for TGLA53 in native cattle; and averaged 0.725 , ranged from 0.476 for SPS115 to 0.873 for TGLA53 in Bal-Tar cross. The polymorphism information content values of the seven from eight observed loci are tending to be high (PIC >0.5) in the studied populations. The highest PIC values were 0.898 , 0.866 and 0.873 in TGLA53 marker in Saidi, Menufi and Bal-Tar cross, respectively; while the lowest PIC values of SPS115 marker were 0.367, 0.238 and 0.476 respectively for the same populations.

Average PIC values in this study, was in close agreement with those reported by Hassanane et al. (2006) working on five local Egyptian cattle populations; where PIC varied from 0.716 for INRA 05 marker of cattle population that locate at Delta district to 0.883 for HEL09 marker of cattle population that locate at Domiatt district. PIC was averaged 0.720 \pm 0.02 across cattle breed groups includes Angus, Brangus, and their crosses with Brahman using ETH10 (DeAtley et al. 2011).

Qiu (2007) analyze the genetic diversity of the Xiangxi cattle used 6 SSR and found 65 alleles in total. PIC average of 6 SSR loci in Xiangxi cattle was more than 0.5 , which indicated that the genetic diversity of Xiangxi cattle was rich.

Agung et al. (2016) reported that the PIC value of the 12 observed loci is high (PIC>0.5) and the highest PIC value in the Simmental cattle population was 0.893 for locus TGLA53. Kesvulu et al. (2009) reported that the overall mean estimate of PIC was 0.628 and it ranged from 0.308 for ETH225 to 0.809 for TGLA122

\section{Intra-breed genetic variation}

Table 3 shows means of observed heterozygosity $\left(\mathrm{H}_{\mathrm{obs}}\right)$ and expected heterozygosity $\left(\mathrm{H}_{\exp }\right)$ as gene diversity values, the chi-square test for Hardy-Weinberg equilibrium (HWE) and Wright's $F_{\text {is }}$ in studied populations. Within breed genetic variability is relatively high, as evidenced by the high mean expected heterozygosity $\left(\mathrm{H}_{\mathrm{exp}}=0.75\right)$.

Table 2. Number of alleles, PIC, PA (Size in bp, Freq.), and $n_{a}$ of the studied SSR

\begin{tabular}{|c|c|c|c|c|c|}
\hline \multirow{2}{*}{$\begin{array}{l}\text { SSR } \\
\text { Marker }\end{array}$} & \multirow{2}{*}{ Term } & \multicolumn{3}{|c|}{ Cattle populations } & \multirow{2}{*}{$\begin{array}{c}\text { Total } \\
\text { Number of } \\
\text { alleles }\end{array}$} \\
\hline & & Saidi & Menufi & Bal-Tar & \\
\hline \multirow{2}{*}{ BM1818 } & No of alleles & 8 & 8 & 10 & 10 \\
\hline & PIC & 0.693 & 0.712 & 0.795 & \\
\hline \multirow{3}{*}{ BM1824 } & No of alleles & 5 & 5 & 5 & 7 \\
\hline & PIC & 0.689 & 0.608 & 0.667 & \\
\hline & PA & & & $(191: 0.367)$ & \\
\hline \multirow{2}{*}{ BM2113 } & No of alleles & 9 & 12 & 12 & 13 \\
\hline & PIC & 0.760 & 0.846 & 0.841 & \\
\hline \multirow{3}{*}{ ETH10 } & No of alleles & 9 & 10 & 8 & 10 \\
\hline & PIC & 0.839 & 0.828 & 0.651 & \\
\hline & PA & & $(205: 0.250)$ & & \\
\hline \multirow{2}{*}{ ETH225 } & No of alleles & 8 & 8 & 8 & 9 \\
\hline & PIC & 0.773 & 0.752 & 0.741 & \\
\hline \multirow{2}{*}{ SPS115 } & No of alleles & 6 & 3 & 3 & 6 \\
\hline & PIC & 0.367 & 0.238 & 0.476 & \\
\hline \multirow{2}{*}{ TGLA53 } & No of alleles & 14 & 12 & 15 & 16 \\
\hline & PIC & 0.898 & 0.866 & 0.873 & \\
\hline \multirow{3}{*}{ TGLA126 } & No of alleles & 5 & 4 & 7 & 7 \\
\hline & PIC & 0.670 & 0.592 & 0.752 & \\
\hline & PA & & & $(119: 0.271)$ & \\
\hline \multirow{2}{*}{ Total } & $\mathrm{n}_{\mathrm{a}} \pm \mathrm{SD}$ & $8 \pm 2.9$ & $7.75 \pm 3.5$ & $8.5 \pm 3.8$ & $9.75 \pm 3.4$ \\
\hline & No of alleles & 64 & 62 & 68 & $78 \pm 2.2$ \\
\hline
\end{tabular}

PIC $=$ Polymorphic information content, $\mathbf{P A}=$ Private alleles, $\mathrm{n}_{\mathrm{a}}=$ Mean of observed number of alleles. 
Table 3 Estimates of intra-breed genetic variation of observed and expected heterozygosity and Hardy Weinberg Equilibrium for the studied populations

\begin{tabular}{lccccc}
\hline Populations & № & Hobs \pm SE & Hexp \pm SE & HWE test & Fis \\
\hline Saidi & 41 & $0.71 \pm 0.025$ & $0.75 \pm 0.055$ & 0.0005 & 0.048 \\
Menufi & 21 & $0.62 \pm 0.038$ & $0.73 \pm 0.073$ & 0.0000 & 0.148 \\
Bal-Tar cross & 35 & $0.86 \pm 0.021$ & $0.77 \pm 0.040$ & 1.0000 & -0.118 \\
All & 97 & $0.73 \pm 0.028$ & $0.75 \pm 0.056$ & --- & 0.026 \\
\hline
\end{tabular}

$\mathbf{H}_{\text {obs }}=$ Mean of observed heterozygosity, $\mathbf{H}_{\text {exp }}=$ Mean of expected heterozygosity, $\mathbf{H W E}=$ Hardy-Weinberg equilibrium, $\mathbf{F}_{\text {is }}=$ Wright's $\mathrm{F}_{\text {is }}$

The present means of $\mathrm{H}_{\exp }$ and $\mathrm{H}_{\mathrm{obs}}$ for Bal-Tar cross were 0.77 and 0.86 , respectively; these results were the highest values among the three studied populations, which might be due to recombination of F1 crossbreeding. Also the crossbred population is the only one showing negative value of heterozygosity deficiency estimate as a result of outbreeding strategy in mating. These results were higher than those reported for pure Tarentaise by Maudet et al. (2002), who found that means of $\mathrm{H}_{\exp }$ and $\mathrm{H}_{\mathrm{obs}}$ were 0.699 and 0.685 , respectively. On the contrary, mean observed heterozygosity was lower than the expected and $F_{\text {is }}$ were positive in the two native Egyptian populations indicating heterozygosity deficiency it may be due to uncontrolled inbreeding as a mating strategy at these areas for a long time.

Deviation from HWE was significant in the two Egyptian populations and non-significant in the Bal-Tar cross. Mean values of heterozygosity estimates in native cattle were higher in Saidi than Menufi (Table 3), and the Menufi cattle showed the least number of observed heterozygosity (0.62). These results indicated that Menufi population has the least genetic variability and the highest inbreeding coefficients among the populations studied.

Numbers of Menufi cattle population decreases and relying on village-bull for insemination increases the chance of inbreeding. For the Egyptian populations, Hassanane et al. (2006) reported a general higher $\mathrm{H}_{\exp }$ that ranged from 0.813 to 0.858 in the five local cattle populations studied. This study was ten years ago, during which period, the native cattle populations in delta significantly changed. The high genetic diversity observed in a population could be explained by overlapping generations, mixing of populations from different geographical locations, natural selection favoring heterozygosity or subdivision accompanied by genetic drift. The effect of these factors is more pronounced when the effective population size is very large.

Cymbron et al. (2005) reported that the estimates of expected heterogozity $\mathrm{H}_{\exp }$ were $0.77,0.55$ and 0.68 for 32 animals of Egyptian native population, 38 animals of Salers and 27 animals of Vosges as French breeds, respectively. Kesvulu et al. (2009) reported that the overall mean observed and expected heterozygosities were 0.684 and 0.666 , respectively and ranged from 0.304 to 1.0 and 0.334 to 0.829 , respectively, indicating higher polymorphism of the microsatellite loci in the population of Punganur cattle. Suh et al. (2014) reported that the mean of $\mathrm{H}_{\operatorname{Exp}}$ across loci was $0.733 \pm 0.018$, with estimates per locus ranging from 0.473 (ILSTS005) to 0.893 (TGLA53). For $\mathrm{H}_{\mathrm{Obs}}$, the mean for all loci was $0.667 \pm 0.028$, and the range was between 0.174 (INRA035) and 0.855 (CSRM60).

Chaudhari et al. (2009) reported that the Means of observed and expected heterozygosity were found to be $0.47 \pm 0.24$ and $0.62 \pm 0.21$ in Kenkatha, and $0.53 \pm 0.17$ and $0.68 \pm 0.14$ in Gaolao cattle in India, respectively. Heterozygosity deficit within a population was measured by Wright's $F_{\text {is }}$. Positive $F_{\text {is }}$ values in Menufi and Saidi indicate that individuals in these populations are more related than expect under a model of random mating and were higher $\left(F_{\text {is }}=0.148\right)$ in Menufi than its value for Saidi $\left(\mathrm{F}_{\mathrm{is}}=0.048\right)$ as reported in Table (3), indicated higher inbreeding coefficients in Menufi than Saidi breeds. Negative $F_{\text {is }}$ values in Bal-Tar cross $\left(F_{i s}=-\right.$ 0.118 ) indicate that individuals in this population are less related than expect under a model of random mating.

\section{Genetic differentiation among breeds}

Table 4 shows that pairwise genetic differentiations quantified by $\mathrm{F}_{\text {st }}$ estimates ranged from 0.006 between Saidi and Menufi to 0.085 between the Bal-Tar cross and Menufi. Similarly Nei's (Nei 1987) standard genetic distance ranged between 0.074 between Saidi and Menufi, and 0.393 between Bal-Tar cross and Menufi. Low estimate of genetic differentiation $\left(\mathrm{F}_{\mathrm{st}}\right)$ between the two Egyptian populations reflects high genetic similarity between these breeds. Hassanane et al. (2006) reported Fst estimates, between five indigenous cattle populations, that its absolute value ranged between 0.001 to 0.046 , while Molina-Flores et al. (2011) studying Saidi cattle, reported an average $F_{\text {st }}$ estimate of 0.018 among different Saidi cattle population. All identified SSR alleles in this study 
Faid-Allah et al. Genetic diversity and structure of native Egyptian cattle populations and French-Egyptian Cross via DNA-microsatellite

Table 4. Estimated genetic differentiation (above diagonal) and genetic distance (below diagonal) among studied populations

\begin{tabular}{lcccc}
\hline Populations & & Saidi & Menufi & Bal-Tar cross \\
\hline Egyptian native cattle & Saidi & - & 0.006 & 0.069 \\
& Menufi & 0.074 & - & 0.085 \\
French-Egyptian cross & Bal-Tar & 0.305 & 0.393 & - \\
\hline \hline
\end{tabular}

\# Pairwise $\mathrm{F}_{\mathrm{st}}$ as a measure of genetic differentiation. \#\# Nei's (Nei 1987) standard genetic distance

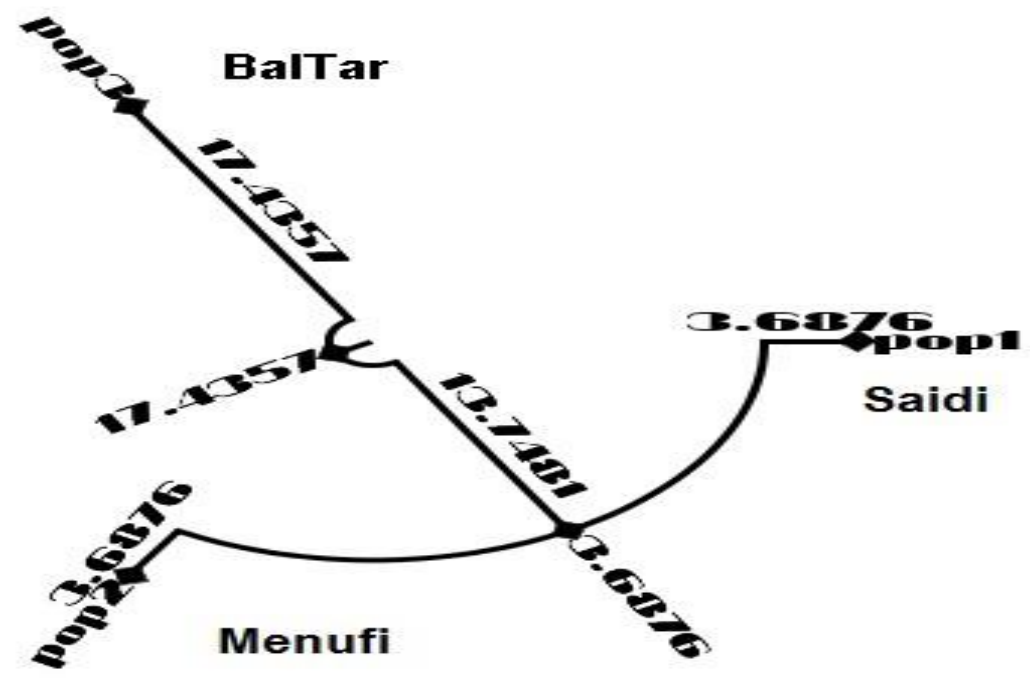

Figure 2. Dendrogram showing the genetic relationship among the three populations of cattle using Ds genetic distance.

were able to classify the studied populations into groups. There are subpopulations that are closely related and form their own group. When the population relationships are visualized with the Dendrogram (Figure 2), Egyptian Menufi and Saidi are together at the same cluster with a low bootstrap value $(20,000)$. Both Egyptian Menufi and Saidi cattle are Nile valley and delta populations. There is only weak differentiation among the Egyptian populations, while the phylogenetic tree shows a clearer differentiation among the native and Bal-Tar cross (Figure 2). Thus, three genetic clusters were identified, that is, two monophyletic clusters coinciding; one Bal-Tar cross and a cluster of the two Egyptian populations. Geographical distribution of (distances among) the three populations is in consistent with the phylogenetic dendrogram (Figure 2). Our results indicated that genetic components of the two Egyptian cattle populations have high level of similarity, which can be due to little genetic divergence among them after their immigration into Egypt out of the center of domestication in the Near East.
Information about the genetic distance in this study confirms Hassanane et al. (2006) who reported that in general gave evidence that all Baladi cattle raised in Egypt have genetic similarities, and could be considered as a one breed. This does not agree with (FAO 1993), which reported that Egyptian cattle have many breeds. The variations in productivity of some populations especially between Domiatt and Saidi, may be due to environmental or management factors.

\section{Genetic structure}

The population structure and the level of admixture in the cattle populations were analyzed by using structure software (Pritchard et al. 2000) which is a model-based clustering analysis, for a $\mathrm{k}$ ranged between 2 to 5 . According to the structure results and the Delta $\mathrm{K}$ estimates, the most probable number for $\mathrm{K}$ was 3 ancestral populations (Figure 3 and 4). The structure analyses generate similar interpretation with the dendrogram (Figure 2). 


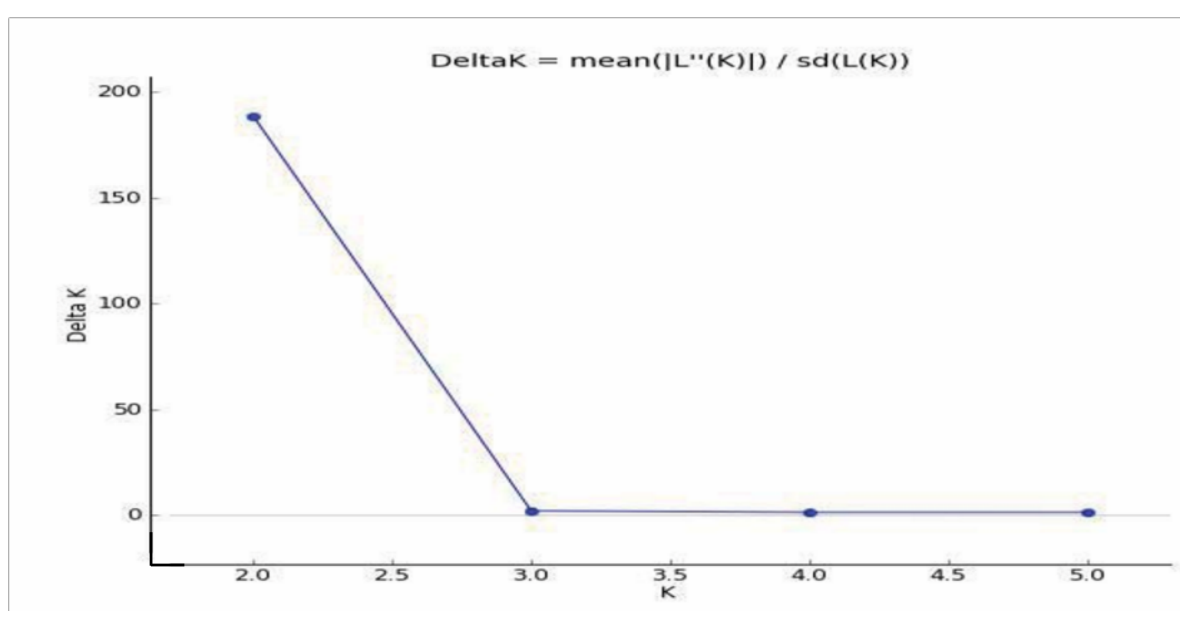

Figure 3. The Delta K estimate.

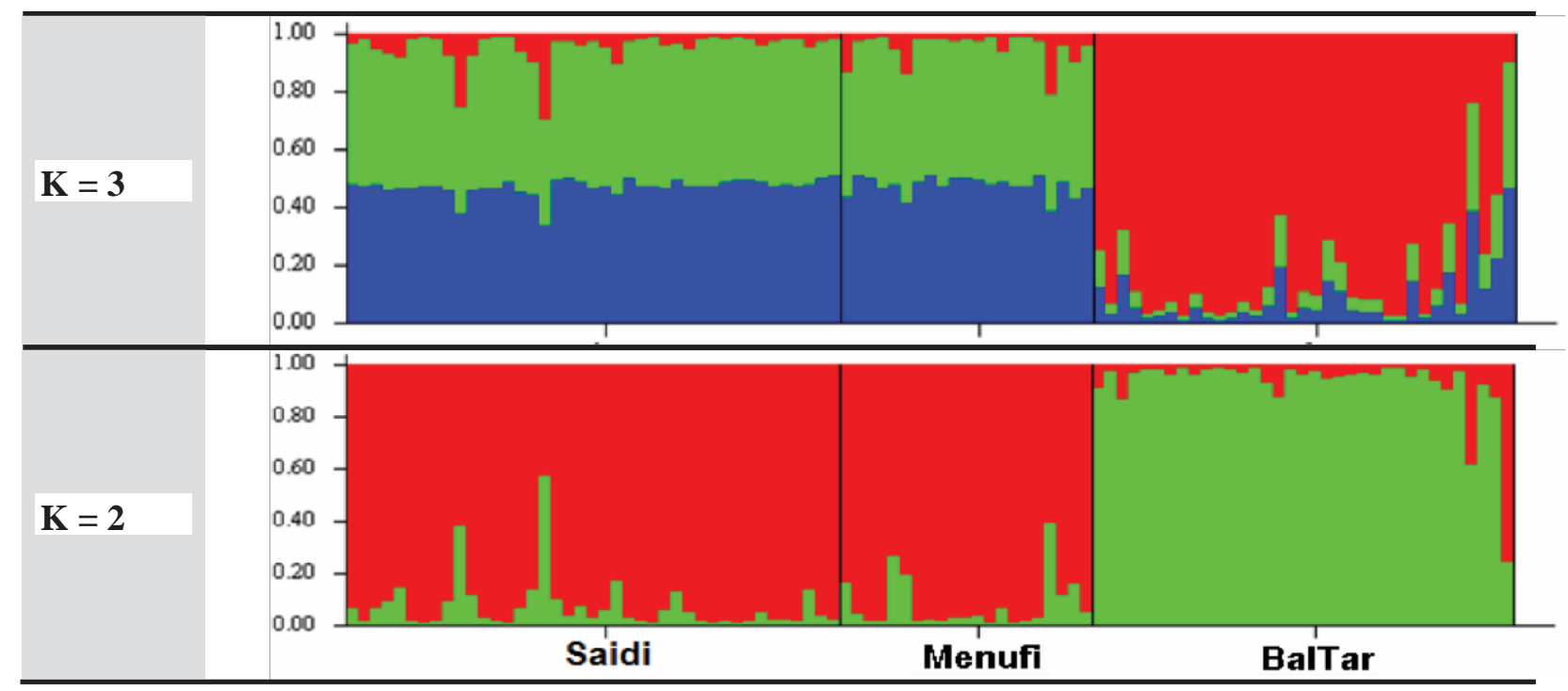

Figure 4. Genetic structure of the studied cattle populations.

Figure 4 shows that structure analysis indicated three ancestral genetic backgrounds. The two native breeds share two main backgrounds in almost equal percentages, while the Bal-Tar cross has the third one. The three populations showed low percentage of admixture with other backgrounds (Figure 4). Such admixture might reflect the inheritance from the common ancestor's from the center of domestication and their movement to the Mediterranean region (South European and North Africa).

Figure 4 shows the genome distribution for each individual in both inferred clusters $(\mathrm{K})$. Each animal is represented by a single vertical bar. The length of the bar color in the vertical axis defines the membership proportion $(\mathrm{Q})$. Where $\mathrm{k}$ is the number of clusters assumed and the length of the colored segment represents the individual's estimated proportion of membership to a particular cluster. Luo et al. (2006) the genetic structure between Yanbian cattle, Yajiang cattle and Changbai local cattle is very similar.

\section{CONCLUSION}

The SSR markers utilized as a part of this work were appropriate in surveying genetic diversity and structure in the Egyptian and crossbred cattle populations analyzed, uncovering elevated amounts of genetic variability. Egyptian cattle populations studied; Egyptian Menufi and Saidi; deviate from HWE and suffer from heterozygosity deficiency, indicating levels of inbreeding, which might be due to decreasing number of reproducing animals and village-cull breeding system. The study indicates that the two 
Egyptian populations and their crosses with the French Tarentaise breed can be genetically differentiated, in line with their geographical distribution and the crossbreeding.

\section{REFERENCES}

[FAO] Food and Agriculture Organization of the United Nations. 1993. Breed database, Map Manager [Internet]. [cited 2017 Nov 21]. Available from: http://dad.fao.org/en/Home.htm.

Acosta AC, Uffo O, Sanz A, Ronda R, Osta R, Rodellar C, Martin-Burriel I, Zaragoza P. 2013. Genetic diversity and differentiation of five Cuban cattle breeds using 30 microsatellite loci. J Anim Breed Genet. 130:79-86.

Agung PP, Saputra F, Septian WA, Lusiana-Moch-Zein SA, Sulandari S, Anwar S, Wulandari AS, Said S, Tappa B. 2016. Study of genetic diversity among Simmental cross cattle in West Sumatra based on microsatellite markers. Asian-Australas J Anim Sci. 29:176-183.

Beja-Pereira A, Alexandrino P, Bessa I, Carretero Y, Dunner S, Ferrand N, Jordana J, Laloe D, Moazami-Goudarzi K, Sanchez A, Canon J. 2003. Genetic characterization of southwestern European bovine breeds: a historical and biogeographical reassessment with a set of 16 microsatellites. J Hered. 94:243-250.

Bishop M, Kappes S. 1994. A genetic linkage map for cattle. Genetics. 136:619-639.

Botstein D, White R, Skolnick M, Davis R. 1980. Construction of a genetic linkage map in man using restriction fragment length polymorphism. Am J Hum Genet. 32:314-331.

Chaudhari M, Parmar S, Joshi C, Bhong C, Fatima S, Thakur M, Thakur S. 2009. Molecular characterization of Kenkatha and Gaolao (Bos indicus) cattle breeds using microsatellite markers. Anim Biodivers Conserv. 32:71-76.

Cymbron T, Freeman A, Malheiro M, Vigne J, Bradley D. 2005. Microsatellite diversity suggests different histories for Mediterranean and Northern European cattle populations. Proc R Soc B. 272:1837-1843.

Dadi H, Tibbo M, Takahashi Y, Nomura K, Hanada H, Amano T. 2008. Microsatellite analysis reveals high genetic diversity but low genetic structure in Ethiopian indigenous cattle populations. Anim Genet. 39:425-431.

DeAtley K, Rincon G, Farber C, Medrano P, Luna-Nevarez J, Enns R, Van Leeuwen D, Silver G, Thomas M. 2011. Genetic analyses involving microsatellite ETH10 genotypes on bovine chromosome 5 and performance trait measures in Angus- and Brahman-influenced cattle. J Anim Sci. 89:2031-2041.

Georges M, Massey J. 1992. Polymorphic DNA markers in Bovidae.

Goudet J. 2001. FSTAT, a program to estimate and test gene diversities and fixation indices version 2.9.3 [Internet]. [cited 2017 Oct 12].:

Hassanane M, El-Ashmaoui H, Abd El-Baset S, Mabrouk M, Abdel-Hameid Z. 2006. Preliminary results on genetic diversity in Egyptian cattle using microsatellite markers. Egypt J Anim Prod. 43:11-24.

Joshi N, Mclaughlin E, Philips R. 1957. Types and breeds of African cattle. Rome (Ital): Food and Agriculture Organization of the United Nations.

Kesvulu P, Rao G, Ahmed A, Gupta B. 2009. Molecular genetic characterization of Punganur cattle. Indian J Vet Anim Sci Res. 5:179-185.

Luo Y, Wang Z, Li J, Zhang G, Chen Y. 2006. Genetic variation and genetic relationship among 13 Chinese and introduced cattle breeds using microsatellite DNA markers. Biodiv Sci. 14:498-516.

MacHugh D, Shriver M, Loftus R, Cunnigham P, Bradley D. 1997. Microsatellite DNA variation and the evolution, domestication and phylogeography of Taurine and Zebu cattle (Bos taurus and Bos indicus). Genetics. 146:1071-1086.

Maudet C, Luikart G, Taberlet P. 2002. Genetic diversity and assignment tests among seven French cattle breeds based on microsatellite DNA analysis. J Anim Sci. 80:942-950.

MoDAD. 2004. Secondary guidelines for development of national farm animal genetic resources management plans, measurement of domestic animal diversity: Recommended microsatellite markers [Internet]. [cited 2017 Aug 19].

Molina-Flores B, Landi V, Martínez A, Delgado J, Galal S, Abdelaziz A. 2011. Caracterización de la raza vacuna Baladi del Alto Egipto mediante microsatélites. AIDA.

Moore S, Byrne K. 1993. Dinucleotide polymorphism at the bovine calmodulin independent adenylcyclase locus. Anim Genet. 24:150-159.

Nei M. 1987. Molecular evolutionary genetics. [New York (USA)]: Columbia University Press.

Ota T. 1993. DISPAN: Genetic distance and phylogenetic analysis software. Pennsylvania (USA): Institute of Molecular Evolutionary Genetics, Pennsylvania State University.

Padilla J, Sansinforiano E, Parejo J, Rabasco A, MartínezTrancón M. 2009. Inference of admixture in the endangered Blanca Cacereña bovine breed by microsatellite analyses. Livest Sci. 122:314-322.

Pham L, Do D, Binh N, Nam L, Ba N, Thuy T, Hoan T, Cuong V, Kadarmideen H. 2013. Assessment of genetic diversity and population structure of Vietnamese indigenous cattle populations by microsatellites. Livest Sci. 155:17-22.

Pritchard J, Stephens M, Donnelly P. 2000. Inference of population structure using multilocus genotype data. Genetics. 155:945-959. 
Qiu Z. 2007. Studies on genetic diversity and correla $\neg$ tion between microsatellite markers and growth traits in Xiangxi Yellow cattle. Changsha (China): Hunan Agricultural University.

Rambaut A. 2012. FigTree (ver.1.4) released 8th, Institute of Evolutionary Biology. Edinburgh (UK): Edinburgh University.

Raymond M, Rousset F. 1995. GENEPOP (ver. 1.2) population genetics software for exact tests and ecumenicism. J Hered. 86:248-249.

Saitou N, Nei M. 1987. The Neighbor-Joining Method: a new method for reconstructing phylogenetic trees. Mol Biol Evol. 4:406-425.

Steffen P, Eggen A. 1993. Isolation and mapping of polymorphic microsatellites in cattle. Anim Genet. 24:121-124.

Suh S, Kim Y, Cho C, Byun M, Choi S, Ko Y, Lee C, Jung K, Bae K, Kim J. 2014. Assessment of genetic diversity, relationships and structure among Korean native cattle breeds using microsatellite markers. Asian-Australas J Anim Sci. 27:1548-1553.

Sun W, Chen H, Lei C, Lei X, Zhang Y. 2007. Study on population genetic charac $\neg$ teristics of Qinchuan cows using microsatellite markers. J Genet Genomics. 34:1725 .

Toldo S, Fries R. 1993. Physically mapped, cosmid-derived microsatellite markers as anchor loci on bovine chromosomes. Mamm Genome. 4:720-727.

Vaiman D, Mercier D, Moazami-Goudarzi K. 1994. A set of 99 cattle microsatellites: characterization, synteny mapping and polymorphism. Mamm Genome. 5:288297.

Yeh F, Yang R, Boyle T. 1999. POPGENE (ver.1.31): A Microsoft Windows-based freeware for population genetic analysis. Edmonton (Canada): Alberta University \& the Centre for International Forestry Research. 